\title{
PENGENALAN "HAND SOAP DAN HAND SANITIZER GEL" BERBASIS ALGAE KEPADA PEMBUDIDAYA RUMPUT LAUT DI TELUK EKAS UNTUK MENCEGAH PENYEBARAN COVID-19 PADA TATANAN KEHIDUPAN BARU
}

\author{
Haji Sunarpi ${ }^{1 *}$, Ahmad Jupri ${ }^{1}$, Eka S. Prasedya ${ }^{1}$, Bq Tri Khairina Ilhami ${ }^{1}$, Anggit L. \\ Sunarwidhi $^{2}$ dan Sri Widyastuti ${ }^{3}$ \\ ${ }^{1}$ Pusat Unggulan Biosains dan Bioteknologi Fakultas Matematika dan Ilmu Pengetahuan Alam, Universitas \\ Mataram, Mataram, Indonesia \\ 2Program Studi Farmasi, Fakultas Kedokteran, Universitas Mataram, Mataram, Indonesia \\ 3Program Studi Ilmu dan Teknologi Pangan, Fakultas Teknologi Pangan dan Agroindustri, Universitas Mataram, \\ Mataram, Indonesia \\ ekajp@yahoo.com*,juprizikril@gmail.com, ekasprasedya@unram.ac.id, baiqtrikhairinailhami@ymail.com, \\ a.sunarwidhi@gmail.com, sriwidyastuti@unram.ac.id
}

\begin{abstract}
Abstrak
Pandemi COVID-19 merubah tatanan kehidupan umat manusia di dunia termasuk di Indonesia. Dalam upaya untuk mencegah penyebaran COVID-19 pada tatanan kehidupan baru, maka perlu ada upaya penyesuaian tatanan kehidupan masyarakat. Berprilaku kehidupan yang bersih, seperti mencuci tangan dengan sabun dan mensterilkan tangan disamping penggunaan masker, merupakan budaya yang harus ditumbuh kembangkan di masyarakat, termasuk para pembudidaya rumput laut. Para peneliti banyak yang melaporkan bahwa rumput laut mengandung antibakteria, antikanker, anti-UV dan antivirus, disamping kandungan fitohormon dan senyawa hidrokoloid, seperti karaginan, agar dan alginat. Karena itu, rumput laut merupakan biota laut yang potensial untuk dikembangkan menjadi sabun cair (hand soap) dan saniter tangan (hand sanitizer). Artikel ini melaporkan pengenalan dan pelatihan pembuatan sabun cair dan saniter berbasis rumput laut yang ada di Teluk Ekas, Kabupaten Lombok Timur. Sasaran pengabdian yaitu para pembudidaya rumput laut, sehingga dalam masa tunggu panen rumput laut, ada aktivitas yang dapat menghasilkan produk untuk mencegah penyebaran COVID19 dan meningkatkan pendapatan masyarakat pesisir.
\end{abstract}

Kata Kunci : rumput laut, sabun cair, saniter tangan, covid-19

\section{PENDAHULUAN}

Pandemi virus SARS-CoV-2/Covid-19 atau yang lebih dikenal dengan istilah corona telah merubah kebiasaan manusia di dunia termasuk di Indonesia. Virus COVID-19 pertama kali ditemukan di kota Wuhan dan tergolong dalam penyakit menular (Santosa 2020). Penularan COVID-19 melalui percikan dari saluran pernapasan penderita kepada orang lain. Gejala umum yang dapat ditimbulkan diantaranya batuk, demam, nyeri tenggorokan, sesak nafas, pilek dan kelelahan (Susilo et al. 2020). Salah satu cara penyebaran virus secara luas melalui media tangan yang telah terpapar virus (Nailufa, 2020).

Berbagai upaya dilakukan untuk mencegah penyebaran COVID-19 diantaranya Pembatasan Sosial Berskala Besar (PSBB), bekerja dari rumah 
(WFH), meningkatkan imunitas dengan mengkonsumsi makanan sehat, rajin berolahraga dan menggunakan masker. COVID-19 juga dapat dicegah dengan berperilaku hidup bersih seperti mencuci tangan yang benar menggunakan hand soap dan hand sanitizer (Utama 2020).

Organisasi kesehatan dunia (WHO) menganjurkan masyarakat untuk rajin mencuci tangan menggunakan sabun untuk meminimalisir penyebaran COVID-19. Sabun terbukti dapat membunuh bakteri, virus dan kuman penyakit. Sabun tersusun atas molekul yang bersifat hidropobik dan hidrofilik sehingga dapat merusak membran COVID-19 (Mustakim et al. 2020). Selain penggunaan sabun (hand soap), sangat dianjurkan untuk menggunakan hand sanitizer. Hand sanitizer merupakan salah satu produk yang berfungsi sebagai antiseptik dan pembersih tangan karena mengandung alkohol 60-90\% sehingga dapat membunuh bakteri dan virus (Nakoe et al. 2020; Niken et al. 2020).

Penggunaan bahan alam dapat dijadikan sebagai pilihan utama pembuatan hand soap dan hand sanitizer. Salah satu bahan alam yang memiliki beragam manfaat yaitu makroalga. Makroalga atau yang dikenal dengan rumput laut merupakan salah satu komoditi utama di perairan Pulau Lombok, khususnya di Teluk Ekas. Makroalga memiliki kandungan sebagai antibakteria (Rizzo et al. 2017), anti kanker (Saeed et al. 2020), anti-UV dan antivirus (Phang, 2010; Riccio et al. 2020). Hal tersebut menjadikan rumput laut dapat dikembangkan sebagai bahan untuk pembuatan hand soap dan hand sanitizer.

Artikel ini melaporkan pengenalan hand soap dan hand sanitizer gel berbasis algae yang terdapat di Teluk Ekas, Kabupaten Lombok Timur. Sasaran dari pengabdian ini yaitu para pembudidaya rumput laut. Seiring dengan meningkatnya kegiatan sehari-hari masyarakat pesisir sehingga membutuhkan hand soap dan hand sanitizer yang dapat digunakan sebagai pembersih tangan dari mikroorganisme maupun virus. Oleh karena itu, pembudidaya rumput laut dapat melakukan pencegahan penyebaran virus COVID-19 terhadap diri sendiri dan keluarga.

\section{METODE}

Pengenalan hand soap dan hand sanitizer gel berbasis algae kepada pembudidaya rumput laut dilakukan pada tanggal 6 September 2020 bertempat di desa Ekas Buana, Kecamatan Jerowaru Kecamatan Lombok Timur. Pengenalan hand soap dan hand sanitizer dilakukan kepada 20 kepala keluarga pembudidaya rumput laut di Teluk Ekas. Tahapan pengenalan produk hand soap dan hand sanitizer berbasis algae adalah sebagai berikut: 1)Peserta Pelatihan dibagi menjadi 2 kelompok, masing-masing kelompok terdiri dari 10 orang; 2) Setiap peserta wajib menjaga jarak dengan peserta lainnya; 3) Bahan-bahan dan proses pembuatan hand soap dan hand sanitizer dijelaskan melalui video tutorial; 4) Pengenalan hand soap dan hand sanitizer berbasis algae coklat dilakukan oleh tim pengabdian PUBB; 5) Seluruh peserta pengabdian diberikan kesempatan untuk mencoba hand soap dan hand sanitizer; 6)Seluruh peserta mengisi kuisioner sebagai uji akseptabilitas terhadap produk hand soap dan hand sanitizer yang meliputi penilaian warna, aroma, tekstur, kestabilan busa dan rasa lengket saat pemakaian.

\section{HASIL DAN PEMBAHASAN}

Pengenalan hand soap dan hand sanitizer gel berbasis algae kepada pembudidaya rumput laut di Desa Ekas Buana, Kecamatan Jerowaru, Kabupaten Lombok Timur. Seluruh peserta berjumlah 20 orang dan dibagi dalam 2 kelompok. Kegiatan pengenalan diawali dengan pembukaan dan pengarahan terhadap keutamaan penggunaan hand soap dan hand sanitizer berbahan dasar algae untuk mencegah COVID-19 (Gambar 1). Disamping itu, pembudidaya rumput laut juga dijelaskan proses pembuatan dan pemanfaatan rumput laut sebagai bahan baku pembuatan produk melalui tayangan video. 


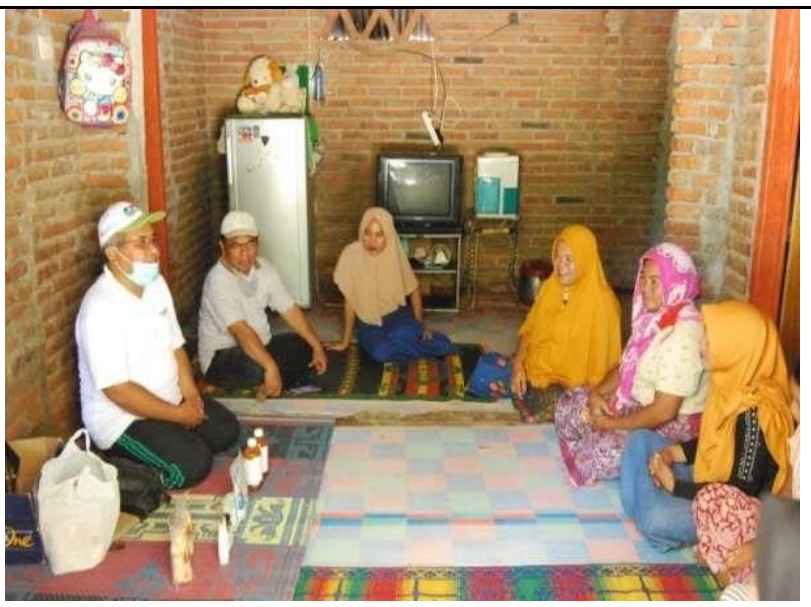

Gambar 1. Sosialisasi pengenalan hand soap dan hand sanitizer kepada pembudidaya rumput laut di Teluk Ekas

Produk hand soap dan hand sanitizer (Gambar 2) diberikan pada seluruh pembudidaya rumput laut. Pembudidaya rumput laut mencoba kedua produk tersebut kemudian mengisi kuisioner berkaitan dengan uji akseptabilitas produk.
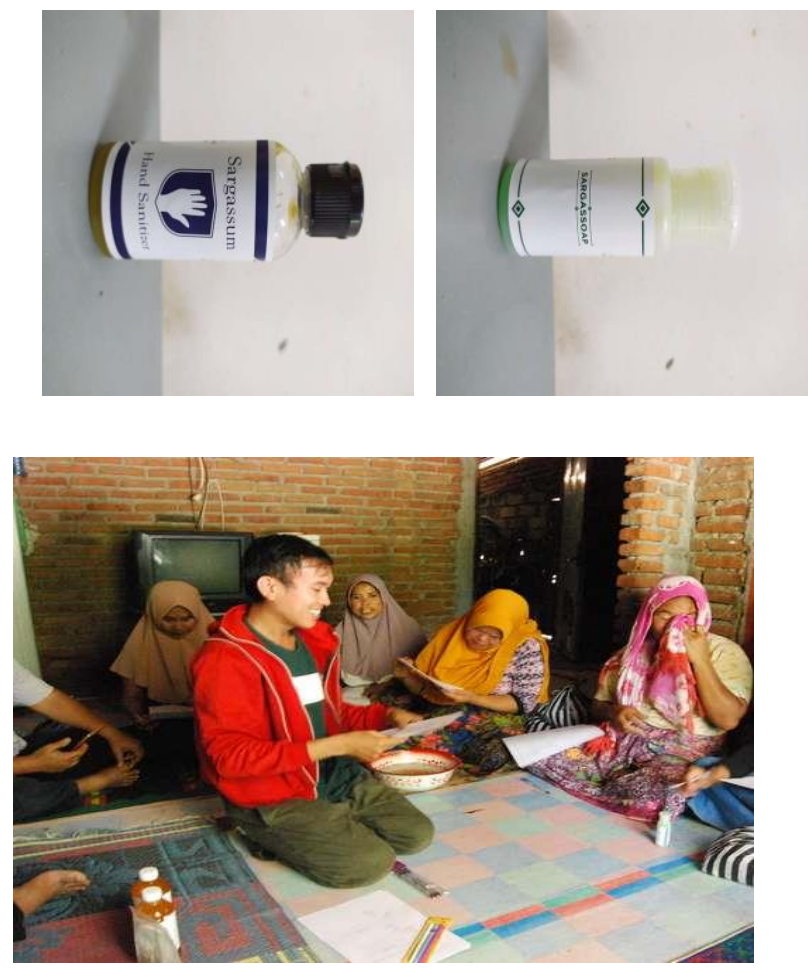

Gambar 2. Kemasan produk dan uji akseptabilitas
Hasil uji akseptabilitas menunjukkan pembudidaya rumput laut menyukai tekstur, warna, aroma dari hand soap dan hand sanitizer. Pembudidaya rumput laut sangat antusias dan tertarik untuk mengikuti serangkaian acara kegiatan. Penggunaan produk hand soap dan hand sanitizer gel berbasis rumput laut tidak hanya dapat mencegah penyebaran COVID-19 tetapi juga pembudidaya dapat memanfaatkan komoditi rumput laut di era pandemi.

Formulasi kedua produk sudah melewati uji akseptabilitas, ekonomis, dan sangat mudah dijangkau. Formulasi hand soap dan hand sanitizer berbasis algae coklat ditunjukkan pada Tabel 1 dan Tabel 2 di bawah ini.

Tabel 1. Formula hand soap

\begin{tabular}{ccc}
\hline Nama Bahan & Kegunaan & Konsentrasi \\
\hline $\begin{array}{c}\text { Sodium Lauryl } \\
\text { Sulfat }\end{array}$ & Cleansing & $5 \%$ \\
Sodium sulfat & Cleansing & $5 \%$ \\
Foam booster & Pengemulsi & $20 \%$ \\
$\begin{array}{c}\text { Ekstrak rumput } \\
\text { laut }\end{array}$ & Zat aktif & 1 gram \\
Pewangi & Pewangi & $5-7$ tetes \\
Pewarna & Pewarna & $5-7$ tetes \\
Aquadest & Pelarut & Ad 100\% \\
\hline
\end{tabular}

Tabel 2. Formula hand sanitizer

\begin{tabular}{ccc}
\hline Nama Bahan & Kegunaan & Konsentrasi \\
\hline $\begin{array}{c}\text { Ekstrak rumput } \\
\text { laut }\end{array}$ & Zat aktif & $1 \%$
\end{tabular}




$\begin{array}{ccc}\text { Carbopol } & \text { Pengental } & 0.739 \% \\ \text { Gliserin } & \text { Humektan } & 1.860 \% \\ \text { Trietanolamin } & \text { Pengemulsi } & 2.901 \% \\ \text { Metil parabean } & \text { Pengawet } & 0.2 \% \\ \text { Propil parabean } & \text { Pengawet } & 0.1 \% \\ \text { Pewangi } & \text { Pewangi } & 5-7 \text { testes } \\ \text { Aquadest } & \text { Pelarut } & \text { Ad 100\% }\end{array}$

\section{KESIMPULAN}

Produk hand soap dan hand sanitizer telah melalui uji akseptabilitas. Penambahan ekstrak alga coklat pada produk hand soap dan hand sanitizer berfungsi sebagai anti-virus dan anti-bakteri. Hasil dari kegiatan pengabdian ini memberikan dampak positif kepada pembudidaya rumput laut di Teluk Ekas, Kabupaten Lombok Timur. Pembudidaya memahami bahma komoditi rumput laut dapat diolah tidak hanya sebagai pangan namun menjadi berbagai macam produk inovatif dengan harga jual yang lebih tinggi sehingga dapat meningkatkan pendapatan masyarakat pesisir.

\section{UCAPAN TERIMAKASIH}

Penulis mengucapkan terimakasih kepada dewan DRIN Riset dan Inovasi Kemenristek RI yang telah menyediakan anggaran pengabdian masyarakat PPDM tahun 2020, rektor Universitas Mataram dan seluruh pihak yang telah berpartisipasi dan berkontribusi selama kegiatan berlangsung, terutama kelompok masyarakat pembudidaya rumput laut di Teluk Ekas, Kecamatan Jerowaru, Kabupaten Lombok Timur.

\section{REFERENSI}

Mustakim Z, Purwaningtyas FH dan Irsadi RS. 2020. Pembuatan dan Pembagian Hand Sanitizer sebagai Upaya Pencegahan Covid-19 di
Desa Dahan Rejo Lor Kabupaten Greseik. Journal of Community Service 2(3): 482-487.

Nailuva Y. (2020) Formulasi dan Evaluasi Gel Hand Sanitizer dengan Moisturizer Alga Hijau (Spirulina platensis) dan Vitamin E. Syntax Idea, 2(6): 156-165.

Nakoe MR, Lalu NAS dan Mohamad YA. 2020. Perbedaan Efektivitas Hand-Sanitizer dengan Cuci Tangan Menggunakan Sabun sebagai Bentuk Pencegahan Covid-19. Jambura Journal of Health Sciences and Research 2(2): 65-70.

Niken, Arman E, Morika HD. 2020. Lawan Covid-19: Stikes Syedza Saintika Salurkan Hand Sanitizer sebagai Wujud Pengabdian Masyarakat. Jurnal Abdimas Saintika, 2(1): 91-95.

Phang, Sie Moi. 2010. Potential Products from Tropical Algae and Seaweeds, Especially with Reference to Malaysia. MJS, 29(2): 160-166.

Riccio G, Ruocco N., Mutalipassi, M., Costantini M., Zupo V, Coppola D, Pascale D and Lauritano C. (2020) Ten-Year Research Update Review: Antiviral Activities from Marine Organisms. Biomolecules, 10(1007): 2-36.

Rizzo C, Genovese G, Morabito M, et al. (2017) Potential Antibacterial Activity of Marine Macroalgae against Pathogens Relevant for Aquaculture and Human Health. Journal of Pure and Applied Microbiology, 11(4): 1695-1706.

Susilo A, Rumende CM, Pitoyo CW, Santoso WD, Yulianti M, Kurniawan H, Sinto R, Singh G, Nainggolan L, Nelwan EJ, Chen LK, Widharni A, Wijaya E, Wicaksana B, Maksum M, Annisa F, Jasirwan CO, Yunihastuti E. 2020. Coronavirus Disease 2019: Tinjauan Literatur Terkini. Jurnal Penyakit Dalam Indonesia, 7(1): 4567.

Saeed AM, Abotaleb SI, Alam NG, ELMehalawy AA and Gheda SF. (2020) In Vitro Assesment of Antimicrobial, Antioxidant and Anticancer Activities of some Marine Macroalgae. Egypt. J. Bot., 60(1): 81-96.

Utama LJ. (2020). Gaya Hidup Masyarakat Nusa Tenggara Timur dalam Menghadapi Pandemi 
Prosiding PKM-CSR, Vol. 3 (2020)

e-ISSN : 2655-3570

Corona Virus Disease 19 (Covid-19). An-Nadaa:

Jurnal Kesehatan Masyarakat, 7(1): 34-40. 

